\title{
INTELLECTUAL CAPITAL PERFORMANCE OF NON-FINANCE FIRMS IN NIGERIA
}

\author{
Aluwong Dogara Blessed, ACE,CNA, MILRM \\ National Industrial Court of Nigeria
}

\begin{abstract}
The study investigates intellectual capital performance in Nigeria drawing samples from listed non-finance firms on the floor of the Nigerian Exchange Group market. While performance proxied by return on asset is the dependent variable, the independent variables adopted for this study includes structural capital efficiency, capital employed efficiency, human capital efficiency and value-added intellectual capital coefficient. Furthermore, in line with related extant literature, we employed the variable of leverage to control our model. The econometric techniques adopted in this study are the panel fixed and Random effect regression techniques. The empirical result of this study leads to the conclusion that out of the four independent variables adopted in this study, only the variable of human capital efficiency insignificantly affect performance of listed non-finance firms in Nigeria. However, we conclude that structural capital efficiency, capital employed efficiency and valueadded intellectual coefficient significantly improve firm performance. On the bases of these findings, we recommend that managers should place great emphasis on structural capital. They need to invest more in its human capital instruments through continuous learning and training. We recommend that managers should provide more towards proper training of employees and ensure that the right persons are selected for the job.
\end{abstract}

KEYWORDS: intellectual capital, performance, non-finance firms, Nigeria

\section{INTRODUCTION}

In Nigeria and likewise in many other countries around the globe, it is observed that firms prepare financial statements at the end of their accounting year or any period usually yearly i.e., twelve (12) calendar months. In preparing these financial statements, assets and liabilities are reported at their net book values (carrying amount) to determine the financial performance and position of the firm and ultimately, the net worth of the business (Okoye, et., al, 2019). However, one vital aspect of these financial disclosures which is unduly neglected during the preparation of the financial statement is the reporting of intangible assets (Joshi, Cahill \& Sidhu, 2010; Lipunga, 2014; Asiaei \& Jusoh 2017; Bayraktaroglu, Calisir \& Baskak 2019). Specifically, Omoye (2013) describe intangible asset as an identifiable non-monetary asset without physical substance. Knowledge, human capital, information (data), reputation (goodwill) and organizational practices, are examples of intangible assets as they cannot be touched, grasped, easily costed, counted, and quantified. Kurfi, Udin and Bahamman (2017) explain that intangible assets are other types of assets besides tangibles and include the attitude of the workforce, which are progressively getting to be important towards deciding future 
profits as economies of the world are transforming from manufacturing base towards knowledge-based economic activity.

As noted in the study of Cao, Cai, Yang \& Ye (2019) the 21st century is more dominated by knowledge economy, many firms are shifting from using physical capital towards embracing intellectual capital, (in which this study is anchored) as more and more firms are trying to find better ways to use their resources efficiently in order to be sustained in the dynamic changing business environment, hence there is a drastic move from production to knowledge and from production labour to knowledge worker among firms (Lipunga, 2014). It is no secret that the organization that continues to invest in new skill and technology will continue to be successful. Intangible assets especially knowledge is gaining prominence than ever before as a matter of survival and of achieving competitive advantage for the firm to compete strategically (Latif, Malik \& Aslam 2012). In today's fast-moving economy with the rapid growth of knowledge and technology innovation, the growth of organization has changed to cope with the changing environment. With mounting competitions in the global economy intellectual capital has become the main ingredient and vital for the organization to sustain the competitive world in which they operate and create more values. Hence as opined by Bontis, (2001) intellectual capital has become the critical driver for firms' sustainability.

On the other hand, firm performance as one foremost concerns of business firms is a measure of management productivity reflected in the extent to which financial objectives of a firm have been accomplished. Monetizing financial objective is hinged on the values presented in the financial statements of a firm particularly the statements that show income (i.e. profit and loss account), financial position (i.e. balance sheet), and the flow of funds. Of these three, the statement of income is recognized globally and used to express the financial results or performance over a period usually over a period of one year. The main source of data for determining firm financial performance is the financial statement, the product of accounting which consists of the balance sheet that shows the assets liabilities and equities of a business, the income statement that records the revenues, expenses and profits in a particular period, the cash flow statement which exhibits the sources and uses of cash, and the statement of changes in the owners' equity that represents the changes in owner's wealth. Firm financial performance is commonly reflected in the calculation of financial ratios that show the link between numbers in the financial statement.

Intellectual capital consists of intangible assets that can be converted into profits (and value) but are not reflected in firm financial statements (Bontis, 1988; Hunter, Webster \& Wyatt 2005). Researchers have highlighted different elements of intellectual capital depending on the research goals. Commonly, studies classify intellectual capital into three components: human capital (skills, experience, and competencies of employees); structural capital (processes, methods, and brands owned by a company); and relational capital (relation network). Intellectual capital positively affects firms' performance and encourages the process of value creation (Cavicchi, (2017); Januškaite \& Užien (2018); Haris, Yao, Tariq, Malik \& Javaid 2019; Chowdhury, Rana \& Azim 2019). In the views of Gołacka, Jefmanska, \& Jefmanski, (2020), intellectual capital is the source of sustainable development. Further, In the knowledge economy, intellectual capital as an intangible resource can help a firm generate economic returns and build competitive advantage along with tangibles (Jardon 2015; Xu \& Wang 2018; 
Oppong, Pattanayak, \& Irfan 2019; Cisneros, Perlines, \& Garcia, 2020; Xu \& Liu 2021). The critical role of intellectual capital for the firm in balancing innovation and exploitative activities is further emphasised in the present fourth industrial revolution era (Mahmood \& Mubarik, 2020), therefore, going forward, intellectual capital is the key assets for firm survival.

On top of the impact of digitalization, the world was hit with an unprecedented crisis in year 2020. The corona virus (COVID-19) pandemic necessitated stay-at-home orders across the globe, and aggressive restrictions still ensue today as the pandemic persists. Corporations were forced, and are still forced in some respects, to continue operating without being able to leverage their physical assets to drive firm performance. Hence, they relied on, and continue to rely on, leveraging their intellectual capital assets at unseen levels to continue fueling corporate performance despite a crippling economic environment. Therefore, it is against this backdrop that this study is necessitated. Summarily, we add to related existing knowledge in two distinct ways. First, this empirical study is among the first that analyzes intellectual capital in Nigeria drawing samples from firms listed within the non-finance sectors of a developing market (Nigeria). This study tries to extend the intellectual capital discourse to less developed countries as previous studies have focused majorly on developed countries.

\section{CONCEPTUAL LITERATURE}

\section{Firm Performance}

In the views of Ranzijn and Verboom (2004), firm performance is understood as bottom line, which means profit. Thus, performance of a company might be judged from profit generating potential of an organization. According to International Accounting Standard (IAS) 1, the purpose of preparing financial statements is to ascertain the financial performance (profit \& loss) position, (solvency and survival), indicating how rich or poor the firm is at a given period of time. Performance is an element of financial statements and frequently the maximization of profits is regarded as the determinant of financial performance or as a basis of other measures. A company should earn profits to survive and grow over a prolonged period (Pandey, 1996). Information about a firms' financial performance is useful in predicting the capacity of the firm to generate cash flows from existing resource base.

Further, firm financial performance is defined as a measure of the extent to which a firm uses its assets to run the business activities to revenues. It examines the overall financial health of a business over a given period and can be used to contract the performance of identical firms in similar industries or between industries in general (Atrill, \& McLaney, 2009). The main source of data for determining firm financial performance is the financial statement, the product of accounting which consists of the balance sheet that shows the assets liabilities and equities of a business, the income statement that records the revenues, expenses and profits in a particular period, the cash flow statement which exhibits the sources and uses of ash in period, and the statement of changes in the owners' equity that represents the changes in owner's wealth. Firm financial performance is commonly reflected in the calculation of financial ratios that show the link between numbers in the financial statement. 


\section{Intellectual Capital Performance}

The concept of intellectual capital (hereafter referred as IC) was first introduced by Galbraith (1969). He posited that IC is "the process of value creation." Subsequently, Kaplan and Norton (1996a) argued that IC includes investments in suppliers, customers, employees and technology. Bell (1997) defined IC as a resource that an organization utilizes to create competitive advantage, including the forms, strategies and special methods. Stewart (1997) thought of IC as the synthesis of knowledge, information, skill, experience and learning ability. Edvinsson and Malone (1997) and Archer et al. (1998) argued that IC is hidden between market and book value of a firm. Although IC definition is not consistent among scholars, it is indeed an intangible asset that can generate wealth to firms. Scholars have classified IC into different components. Brooking (1996) think that IC comprises of human capital, structural capital, market capital and knowledge property rights capital. Edvinsson and Malone (1997) classified IC into human capital and structural capital. Human capital deals with employees' competence, attitudes and intelligence, while structural capital includes organizational structure, facilities and equipment. Similarly, Sveiby (1997) divided intellectual capital into human capital, structural capital, and customer capital.

Subsequently, customer capital was replaced with relational capital by some researchers like Stewart (1997) who classified intellectual capital into human capital, structural capital and relational capital where relational capital contains the value and knowledge from corporate networks with customers, suppliers, distributors, competitors and all other related parties. Even though there exist different intellectual capital classifications, intellectual capital is generally suggested as the composition of human capital, structural capital, and relational capital (Stewart, 1997; Sveiby, 1997; Andriessen, 2004).

\section{Capital Employed Efficiency}

Capital employed refers as the amount of capital used in current and fixed assets of the firm. It is the same fund shareholders' capital or long-term liabilities plus equity or loan capital. In terms of assets, it is equal to the working capitals and fixed asset. Therefore, the capital uses summarize asset values led to the company's ability to create income and it is also known as operating assets. The money is often funded through two methods shareholder equity financing and net debt. It is an asset in the long direct control manager and typically includes accounts receivable, inventory and plant and equipment (Nik Maheran, 2009).

\section{Structural Capital Efficiency}

Structural capital is an organization's ability to meet the company routines and structures that support employee efforts to produce optimal intellectual performance as well as overall business performance, for example: the company's operational systems, manufacturing processes, organizational culture, management philosophy and all forms of intellectual property are owned by the company. An individual can have a high intellectual level, but if the organization has poor systems and procedures such intellectual capital cannot achieve optimal performance. Structural capital is the infrastructure that supports employees to create optimum performance, including the ability of the organization to reach the market, hardware, software, 
databases, organizational structure, patent, trademark, and all the ability of organizations to support employee productivity (Bontis, 2000). The concept of the existence of structural capital allows the creation of intellectual capital and be a liaison / processing of human resources into intellectual capital. Structural capital is the expertise or 'know-how' that belongs to the firm's property after the contribution induced by human skill (Bontis, 1998). Structural capital is what belongs to the firms, including innovative capital, relational capital, and organizational infrastructure, etc. (Roos et al. 1997). Similarly, Nik Maheran (2009) mentioned that structural capital encompasses the enabling structures that allow the organization to exploit the intellectual capital. The structure ranges from tangible items offered by an organization such as patents, trademarks, and databases, to complete intangible success such as culture, transparency, and trust among employees. This capital is resulted from the products or systems that firm has created over time and will remain with the enterprise when people leave (Maheran, 2009). Thus, organizations that possess strong structural capital will have a supportive culture that permits their employees to try new things, to learn and to practice them (Bontis et al, 2000).

\section{Human Capital Efficiency}

The term human capital is defined as a combination of the following four factors - genetic inheritance; education; experience; and attitudes about life and business (Ogbo, Ezeobi \& Ituma, 2013). Human capital is one of the essential variables in the study of intellectual capital, and it is the dimension of intellectual capital which deals with human knowledge, and which influences a firm's value by affecting the other elements (Ogbo, Ezeobi \& Ituma 2013). According to Ahangar (2011), human capital is recognized as the largest and the most important intangible asset in an organization that provides the goods and/or services that customers require to solve their problems. It includes the collective knowledge, competency, experience, skills, and talents of people within an organization. Human capital value is not reported to stakeholders partially owing to strict criteria for intangible assets' recognition which prevent human resources to be shown as an asset in the balance sheet (Tayles, Pike \& Sofian 2007). The information related to any activities and decisions made by key personnel that contribute to competitive advantage and "hidden" value for the companies is often not disclosed, hence analysts need to incur extra cost to seek confidential information on the "value creators" of the companies. Human capital is measured by total expenditures that company spent on its human capital. Total salary and wage costs are indicators of a firm's human capital and human capital efficiency is calculated as the ratio of total Value Added (VA) divided by the total salary and wages spent by the firm on its employees.

\section{Value Added Capital Efficiency}

Measuring intellectual capital's value is not an easy procedure because financial reports do not supply needed information about intangibles. Thus, scholars seek different approximations and develop various approaches to measuring intellectual capital. Goebel (2015) categorizes these approaches into three groups, depending on the information sources used. The first group represents component-based approaches which in essence is the estimation of single intellectual component. After the intellectual capital components are determined, a researcher can measure the aggregate value of intellectual capital. Goebel (2015) summarizes that this 
group of approaches is rarely used because there is a lack of available information regarding individual intellectual capital components. In addition, Mouritsen Mouritsen (2009), note that the unobservable interactions of intellectual components are hidden when component-based measures are applied. The interaction effect contributes considerably to the intellectual capital value (Kooistra \& Zijlstra 2001). The second group contains holistic market-based approaches. Holistic market-based approaches assume that intellectual capital and the interaction effects of the intellectual capital elements can be fully captured in the overall value. Penman (2009) argued that intellectual capital increases earnings with an effect on company value. Thus, intellectual capital can be observed as the disparity between firms' market value and their book value. However, measures that are related to holistic market-based approaches do not allow estimating components of intellectual capital. The third group consists of investment-based approaches that are based on financial statement information. All costs related to intellectual capital are considered as investments in intellectual capital when investment-based approaches are applied. For example, labour expenses can be considered human capital investments. Investment-based approaches allow estimating intellectual capital components based on objective financial information about cash flows related to each of the intellectual capital components. Goebel (2015) emphasized VAIC as the most important model related to investment-based approaches. Pedro, Leitão \& Alves (2018) also noticed that the VAIC methodology is the most popular among scholars by emphasizing that; VAIC can show the efficiency of the intellectual capital elements unlike other relevant intellectual capital financial metrics such as economic value added (EVA) (Pulic, 2004). VAIC avoids using unavailable, subjective and qualitative information that cannot be translated into quantitative values (Clarke, Seng \& Whiting 2011). VAIC allows cross-organizational and cross-national comparison (Nimtrakoon, 2015). Firer and Williams (2003) claimed that the other models of intellectual capital measurement are customized to fit a specific firm's profile, which limits comparability.

\section{Theoretical Review}

\section{Theory of Dynamic Capabilities}

The relationship between knowledge component and resources component in the produced outputs has changed significantly, thus contributing to the change in the source of competitive advantage. In the past, competitive advantages were based on the market dominance or organization of the process of mass production, while in modern circumstances competitive advantage lies in brand and reputation, patents and standards, relationships with employees, suppliers, and customers. These sources of competitive advantage represent various forms of intellectual capital, which could create huge differences between the book value of a firm and its market value, which also encompass a value of the undisclosed intellectual capital (Hunter, 2002). Competitive advantage in business is essentially based on a variety of unique competencies, i.e., capabilities to do things others cannot. What happened in the 20th century is that the sources of these different, unique competencies changed in the revolution towards the knowledge economy. In the knowledge economy, a firm is successful not just in hiring of talented people, but they need to add value to them, hence it is necessary to distinguish between the contributions of the organization and the contributions of individuals (Kay, 2000). While intellectual resources are embedded in the experience and expertise of individuals, firms provide physical and social resources, as well as the structure of resource allocation, that allows 
the transformation of knowledge i.e., intellectual resources in competencies (Teece, 2000). The way in which these competencies and intellectual resources are configured and employed will greatly affect the competitive position and the commercial success of a firm.

Given that the current assets of a firm are mainly intangible, it is unclear which of them belong to the firm, and which part is embedded in employees. In addition, superior technology by itself is not sufficient for creating and sustaining a competitive advantage, but cognitive and managerial skills are also necessary to identify and combine relevant complementary assets for encouraging business (Teece, 2000). In a constantly changing environment, what provides the basis for creating competitive advantages is the ability to recognize and exploit opportunities, i.e., dynamic capabilities (Teece, 2000). Dynamic capabilities represent the abilities of a firm to integrate, create and reconfigure internal and external competencies to respond to extremely volatile environment (Teece, Pisano, \& Shuen, 1997). Dynamic capabilities are to be found in firms that are mainly entrepreneurial oriented, with a horizontal organizational structure, clear vision, high incentives to managers/employees and a high degree of autonomy to ensure rapid response to changes in the dynamic environment (Teece, 2000). Resource performances and dynamic capabilities of a firm set the activities of imitation and experimentation with resources, as well as the assessment of the costs of these activities, and lead to a new structure of resources which, because of learning by imitation and experimentation, determines a future production quantity, product and process innovations (Zott, 2003). In this manner, a firm can be thought of as a value chain which value is created by transformation of the inputs to the outputs, that is, as a set of separate, but interrelated strategically important economic activities in the design, production, delivery and sale of products and services, whose better and more cost-effective performance compared to competitors leads to the competitive advantage (Viedma Marti \& Cabrita, 2012). This practically means that the competitive advantage is the result of the firm's capabilities to accomplish the above-mentioned activities at a lower cost in comparison to the competitors, or in a unique way which enables a firm to determine a higher cost, wherein the structure of the activity, and the way in which they are set, are determined by the strategy of the firm (Viedma Marti \& Cabrita, 2012).

\section{Empirical Review and Hypotheses Development}

\section{Capital Employed Efficiency and Firm Performance}

Several research indicates significant prove of capital employed influence on organization performance. In globalization era, all organization effort has to competitive advantage. To achieved competitive advantage needs both physical capital and intellectual capital. The study result of Hitt et al. (2001) proved the role capital employed more dominant to compare with real capital. Other research indicates that intellectual capital recognized as important resources which give a use for creating organization efficiency, effectiveness, productivity, and innovation better than physical capital and financial capital (Najibullah, 2005). The research result of Pulic (1999) indicates that intellectual capital can create value added for the organization consistent with prior research, intellectual capital has potential as a wealth creator in business organization (Walker, 2001; Usoff et al., 2002; and Karp, 2003). On the basis of the foregoing, we hypothesized that: 
Vol.10, No.1, pp. 1-17, 2022

Print ISSN: 2053-4019(Print),

Online ISSN: 2053-4027(Online)

H0: Capital employed efficiency has no significant effect on the performance of listed nonfinance firms in Nigeria

\section{Human Capital Efficiency and Firm Performance}

Human capital reflects the company's collective ability to produce the best solution based on the knowledge of people who are in the company (Sawarjuwono \& Kadir, 2003). Now companies manage human capital by providing training programs, salaries and financial bonuses, and benefits to create competitive advantage. The better a company manages its resources the better the productivity of assets in generating net income. Ahangar study (2011) showed that human capital efficiency positive affect company performance. Human capital is argued to be a significant factor in doing business (Bontis, et al, 2000). Human capital is highly correlated with intellectual capital as each individual carries skills and knowledge that are important to boost company's performance. Svanadze and Kowalewska (2015) pointed out that intellectual capital is still rarely presented in company's financial report and accounting system for it is intangible. Where in fact, intangible assets are mostly acknowledged by the investors and are one of the main considerations for company and shareholders to make strategic decisions. Martins and Lopes (2016) conducted research to measure European companies' profitability using return on asset and provided results that show a strong relationship between company's knowledge and company's ability to make profit. Their study finds significant differences between company's profit and values measured by including intangible assets and the result measured only by including tangible assets. Their findings support the traditional economic argument that resources owned by the company determine company's performance and profitability. Resources are not limited only to tangibles but also intangible such as intellectual capital owned by each human individual. On the basis of the foregoing, we hypothesized that:

\section{$\mathrm{HO}_{2}$ : Human capital efficiency has no significant effect on the performance of listed non- finance firms in Nigeria}

\section{Structural Capital Efficiency and Firm Performance}

A firm requires structural support, providing its employees with resources and networks, and promoting their duties (Nawaz \& Haniffa, 2017). Scholars conclude that structural capital forms the framework for all other intellectual capital components and tangible assets to be converted into outputs (Ferenhof, Durst, Bialecki, \& Selig, 2015). Apart from human capital, structural capital is also part of the firm's knowledge (Ting \& Lean, 2009). Structural capital is the elements of intellectual capital that remain with the company even without other intellectual capital elements (Carson, Ranzijn, Winefield, \& Marsden, 2004). Structural capital is collated in various ways, including tangible and intangible components. It is the firm's combined investment in its hardware, database or charters, process manuals, procedures, cultures, and intellectual property (Phusavat, Comepa, Sitko-Lutek, \& Ooi, 2011; Ramezan \& Farahani, 2015; Low, Samkin, \& Li, 2015). Structural capital plays a significant role in improving firms' performance, assisting firms to leverage their human resources, and businesses are now focused on building structural capital. Human capital integrates with structural capital, becomes the foundation for relational capital, enhancing customer loyalty to 
firms' products. This is supported by previous studies conducted by Amin and Aslam (2017) which revealed that structural capital has a significant positive effect on company performance. Companies that can manage organizational resources properly will create competitive advantage by employing the ability of the company and the structure that supports employee efforts to generate intellectual capital that is optimal, suggesting that improvements in the company in utilizing intellectual capital owned by the company can increase the level of profit and investor confidence. According to Fajarini and Firmansyah (2012), the management of structural capital efficiency would increase company's financial performance. Prior studies shows that structural capital efficiency have positive affect on financial performance. Bontis, et al (2000); Diva and Mitha (2014); Martins and Lopes, (2016), and Devi, Khairunnisa \& Budiono (2017) argued that structural capital value added has a positive impact on company's performance. A company is expected to have organizational capacity to build a condition that support the employees to optimize intellectual capital and other resources management. On the basis of the foregoing, we hypothesized that:

\section{$\mathrm{HO}_{3}$ : Structural capital efficiency has no significant effect on the performance of listed non- finance firms in Nigeria}

\section{Value Added Intellectual Capital Efficiency and Firm Performance}

Ante Pulic is one of the first scholar to conduct empirical research on Intellectual Capital. Pulic developed the VAIC, in 1998, by using accounting measurements to examine the relationship between intellectual capital and financial performance. This method has paved the road for more extensive research in the measure of intellectual capital efficiency. According to Inkinen (2015) intellectual capital positively affect firms' performance and encourages the process of value creation. Intellectual capital is the source of sustainable development (Cavicchi, 2017; Januškaite \& Užien, 2018; Gołacka, \& Jefmanska, \& Jefmanski, 2020;). Different methods of computing intellectual capital have been provided for in literature (Goebel, 2015; Osinski, Selig, Matos \& Roman, 2017; Ovechkin, Boldyreva \& Davydenko 2020]. In the views of Pedro, Leitão \& Alves 2020), the most popular financial indicator of intellectual capital and its components is the value-added intellectual coefficient (VAIC). Value-added intellectual coefficient shows the efficiency of the intellectual capital elements and allows cross-organizational and cross-national comparison. Ahangar (2011) conducted a study by using value added intellectual capital to measure intellectual capital performance and its impact on financial returns of Iranians companies. The results showed that value added intellectual capital has significant positive impact on financial returns of companies Furthermore, Joshi et.al (2010) conducted a study to measure the intellectual capital performance through value added intellectual capital model. The result show that Human Capital Efficiency (HCE) has significant relationship with efficiency of Australian banks which means more investment on human capital will increase the efficiency of banks. Chu, Chan, $\mathrm{Yu}$, $\mathrm{Ng} \&$ Wong (2011) finds no relationship between intellectual capital (Value added intellectual capital) and the components of business performance (Market to book value, return on asset and Asset turnover) for Hong Kong listed companies. Hussain et al. (2010) using samples from Bangladesh listed companies and find marginal evidence regarding the significance of intellectual capital in influencing market value and financial performance. Clarke, Seng and Whiting (2011) note that there is a positive relationship between performance and the 
components of value-added intellectual capital. Rahman (2012) finds no strong evidence supporting the association between value added intellectual capital and firms' market values. On the basis of the foregoing, we hypothesized that:

\section{H0 $0_{4}$ Valued-added intellectual coefficient has no significant effect on the performance of listed non-finance firms in Nigeria}

\section{METHODOLOGY}

In relation with extant literature, we employed the firm-level approach based on an expo-facto and non-experimental research design. The study is longitudinal covering a period of ten (10) years. That is, from 2011 to 2020 employing listed non-finance firms on the floor of the Nigerian Exchange Group (NGX). The sampling technique employed is purposive since firms were included in the sample on certain selection criteria. These criteria were based on the view that the firms are listed on the Nigerian Exchange Group (NGX) market from 2011-2020; there were access to their annual financial reports within the period and they were not firms operating subsidiaries in Nigeria that are not listed in the Nigerian Exchange Group (NGX). Newly listed firms and delisted firms were excluded from the study. Thus, only non-finance firms that had all relevant data due to continuous existence were included in the sample. Our final sample size consists of 30 non-finance firms that was arrived at based on the availability of data for ten years for all the research variables. Hence, we express our econometric model as

RETAit $=0+1$ SCEEit +2 HCEEit +3 CEEEit +4 DETAit + it ...(1)

$$
\text { RETAit }=0+1 \text { VAICit }+ \text { 2DETAit }+ \text { it...(2) }
$$

\section{Where:}

$\begin{array}{lll}\text { RETA } & = & \text { Return on Asset } \\ \text { SCEE } & = & \text { Structural Capital Efficiency } \\ \text { HCEE } & = & \text { Human Capital Efficiency } \\ \text { CEEE } & = & \text { Capital Employed Efficiency } \\ \text { VAIC } & = & \text { Value Added Intellectual Capital Coefficient } \\ \text { DETA } & = & \text { Debt to Asset } \\ \beta_{0} & = & \text { Constant } \\ \beta_{1}-\beta_{6} & = & \text { Slope Coefficient } \\ \mathrm{i} & = & \text { Stochastic disturbance } \\ \mathrm{t} & = & \mathrm{i}^{\text {th }} \text { firm } \\ & = & \text { time-period }\end{array}$

Thus, our apriori expectations are stated as; $\mathrm{X}_{1}-\mathrm{X}_{4}>0$ : which means that a rise in the determinant variables of structural capital efficiency, capital employed efficiency, human capital efficiency and value-added intellectual capital coefficient will lead to a rise in performance of listed nonfinance firms in Nigeria. The econometric techniques adopted in this study are the panel fixed and Random effect regression techniques. The rationale for its usage is based on the following justifications: the data that will be collected may have time and cross-sectional attributes as 
well as across the sampled firms (cross-section); panel data regression provides better results since it uses large observation and reduces the problem of degree of freedom (Muhammad, 2012); it avoids the problem of multicollinearity and help to capture the individual crosssectional (or firm-specific) effects that the various pools may exhibit with respect to the dependent variable in the model.

\section{EMPIRICAL RESULTS AND DISCUSSION}

The study investigates intellectual capital performance in Nigeria drawing samples from listed non-finance firms on the floor of the Nigerian Exchange Group market. While performance proxied by return on asset is the dependent variable, the independent variables adopted for this study includes structural capital efficiency, capital employed efficiency, human capital efficiency and value-added intellectual capital coefficient. Furthermore, in line with related extant literature, we employed the variable of leverage to control our model. Data set employed in this study spans through the periods between 2011 and 2020. Table 4.1 below describes the data in terms of the companies which they belong. Overall, the descriptive statistics provides some insight into the nature of the selected Nigerian listed non-finance companies that were employed in this study.

\section{Descriptive Analysis}

In this section, we examine the descriptive statistics for both the explanatory and dependent variables of interest. Each variable is examined based on the mean, standard deviation, maximum and minimum. Table 1 below displays the descriptive statistics for the study.

Table 1: Descriptive Statistics

\begin{tabular}{l|ccccc}
\hline \multicolumn{1}{l}{ VARIABLES } & \multicolumn{1}{c}{ MEAN } & SD & MIN & MAX & NO OBS \\
\hline RETA & 5.74 & 11.01 & -52.56 & 53.96 & 299 \\
SCEE & 0.60 & 0.37 & -1.24 & 2.38 & 299 \\
HCEE & 4.71 & 4.46 & -0.73 & 35.72 & 297 \\
CEEE & 0.30 & 0.16 & -0.02 & 1.20 & 299 \\
VAIC & 5.58 & 4.70 & -0.75 & 37.07 & 299 \\
DETA & 56.35 & 18.98 & 4.28 & 123.35 & 299
\end{tabular}

Source: Author (2021)

The table above shows the summary of the descriptive statistics of the study. From the table it is observed that return on asset (RETA) on the average is 5.74 with a standard deviation of 11.01. Structural capital efficiency (SCEE) on the average is observed to be 0.60 with a standard deviation of 0.37 . We also find that Human capital efficiency (HCEE) has a mean of 4.71 with a standard deviation of 4.46. The table also shows that capital employed efficiency (CEEE) had a mean of 0.30 with a standard deviation of 0.16 . Value-added intellectual coefficient has a mean of 5.58 with a standard deviation of 4.70. For our control variable, the table reveal that leverage (DETA) had a mean of 56.35 with a standard deviation of 18.98 . 


\section{Correlation Analysis}

In examining the association among the variables, we employed the Pearson correlation coefficient (correlation matrix) and the results are presented in the table below.

Table 2: Correlation analysis

\begin{tabular}{lllllll}
\hline & RETA & SCEE & HCEE & CEEE & VAIC & DETA \\
\hline RETA & 1.00 & & & & & \\
\hline SCEE & 0.33 & 1.00 & & & & \\
\hline HCEE & 0.36 & $\mathbf{0 . 5 4}$ & 1.00 & & & \\
\hline CEEE & 0.55 & 0.30 & 0.16 & 1.00 & & \\
\hline VAIC & 0.38 & 0.60 & 0.99 & 0.21 & 1.00 & \\
\hline DETA & -0.24 & -0.16 & -0.05 & -0.04 & -0.06 & 1.00 \\
\hline \multicolumn{6}{c}{ Author's computation (2021) }
\end{tabular}

In the case of the correlation between the variables of interest, the above results show that there exists a positive and moderate association between structural capital efficiency and return on asset (0.33). There exists a positive and moderate association between human capital efficiency and return on asset (0.36). There exists a positive and moderate association between capital employed efficiency and return on asset (0.55). There exists a positive and moderate association between value-added intellectual coefficient and return on asset (0.38). In the case of our control variable, we find that there exists a negative and moderate association between leverage and return on asset (-0.24). However, to test our hypotheses a regression results will be needed since correlation test does not capture cause-effect relationship.

\section{Regression Results}

Specifically, to examine the cause-effect relationships between the dependent variables and independent variables as well as to test the formulated hypotheses, we present a panel data regression and an OLS pooled results in the table below.

Table 2: Regression Result

\begin{tabular}{|c|c|c|c|c|c|c|}
\hline & & Model 1 & & & Model 2 & \\
\hline & $\begin{array}{l}\text { RETA Model } \\
\text { (Pooled OLS) }\end{array}$ & $\begin{array}{l}\text { RETA Model } \\
\text { (FIXED Effect) }\end{array}$ & $\begin{array}{l}\text { RETA Model } \\
\text { (RANDOM } \\
\text { Effect) }\end{array}$ & $\begin{array}{l}\text { RETA Model } \\
\text { (Pooled OLS) }\end{array}$ & $\begin{array}{l}\text { RETA Model } \\
\text { (FIXED Effect) }\end{array}$ & $\begin{array}{l}\text { RETA Model } \\
\text { (RANDOM } \\
\text { Effect) }\end{array}$ \\
\hline C & $\begin{array}{l}-0.61 \\
\{0.757\}\end{array}$ & $\begin{array}{l}-1.76 \\
\{0.460\}\end{array}$ & $\begin{array}{l}-1.40 \\
\{0.555\}\end{array}$ & $\begin{array}{l}8.00 \\
\{0.000\} * * *\end{array}$ & $\begin{array}{l}9.49 \\
\{0.000\} * * *\end{array}$ & $\begin{array}{l}9.09 \\
\{0.000\} * * *\end{array}$ \\
\hline SCEE & $\begin{array}{l}0.09 \\
\{0.956\}\end{array}$ & $\begin{array}{l}5.03 \\
\{0.006\} * *\end{array}$ & $\begin{array}{l}3.94 \\
\{0.021\} * *\end{array}$ & & & \\
\hline HCEE & $\begin{array}{l}0.65 \\
\{0.000\} * * *\end{array}$ & $\begin{array}{c}0.21 \\
\{0.129\}\end{array}$ & $\begin{array}{l}0.33 \\
\{0.013\} * *\end{array}$ & & & \\
\hline CEEE & $\begin{array}{l}33.95 \\
\{0.000\} * * *\end{array}$ & $\begin{array}{l}45.05 \\
\{0.000\} * * *\end{array}$ & $\begin{array}{l}39.66 \\
\{0.000\} * * *\end{array}$ & & & \\
\hline
\end{tabular}


Vol.10, No.1, pp. 1-17, 2022

Print ISSN: 2053-4019(Print),

Online ISSN: 2053-4027(Online)

\begin{tabular}{|c|c|c|c|c|c|c|}
\hline DETA & $\begin{array}{l}-0.12 \\
\{0.000\} * * *\end{array}$ & $\begin{array}{l}-0.18 \\
\{0.000\} * * *\end{array}$ & $\begin{array}{l}-0.15 \\
\{0.000\} * * *\end{array}$ & $\begin{array}{l}-0.13 \\
\{0.000\} * * *\end{array}$ & $\begin{array}{l}-0.14 \\
\{0.000\} * * *\end{array}$ & $\begin{array}{l}-0.14 \\
\{0.000\} * * *\end{array}$ \\
\hline VAIC & & & & $\begin{array}{l}0.87 \\
\{0.000\} * * *\end{array}$ & $\begin{array}{l}0.76 \\
\{0.000\} * * *\end{array}$ & $\begin{array}{l}0.79 \\
\{0.000\} * * *\end{array}$ \\
\hline $\begin{array}{l}\text { F-statistics/Wald } \\
\text { Statistics }\end{array}$ & $\begin{array}{ll}53.36 & (0.00) \\
* * * & \\
\end{array}$ & $\begin{array}{ll}38.11 & (0.00) \\
* * * & \\
\end{array}$ & $\begin{array}{ll}170.28 & (0.00) \\
* * * & \\
\end{array}$ & $\begin{array}{ll}\begin{array}{l}19.50 \\
* * *\end{array} & (0.00) \\
\end{array}$ & $\begin{array}{ll}18.62 & (0.00) \\
* * * & \\
\end{array}$ & $\begin{array}{ll}47.22 & (0.00) \\
* * * & \\
\end{array}$ \\
\hline R-Squared & 0.42 & 0.37 & 0.36 & 0.20 & 0.12 & 0.12 \\
\hline VIF Test & 1.27 & & & 1.00 & & \\
\hline Heteroscedasticity Test & $\begin{array}{ll}7.66 & (0.0056) \\
* * & \end{array}$ & & & $2.19(0.1391)$ & & \\
\hline $\begin{array}{l}\text { HAUSMAN TEST } \\
0.8487 \text { ) }\end{array}$ & & Prob $>$ chi2 $=$ & $18.93(0.0008)$ & & & Prob $>$ chi2 $=0.33$ \\
\hline
\end{tabular}

(2) $* *, * * *$, implies statistical significance at $5 \%$ and $1 \%$ levels respectively

In the table above, we observed from the OLS pooled regression that the R-squared value of 0.42 for model 1 and 0.20 for model 2 shows that about $42 \%$ and $20 \%$ of the systematic variations in performance proxied by return on asset in the pooled non-finance firms over the period of interest was jointly explained by the independent and control variables in both models respectively. The unexplained part of performance can be attributed to exclusion of other independent variables that can impact on performance but were captured in the error term. The F-statistic value of 53.36 (model 1) and 19.50 (model 2) and their associated P-value of 0.00 shows that the OLS regression of both model on the overall is statistically significant at $1 \%$ level, this means that the regression models is valid and can be used for statistical inference. The table above also shows a mean VIF value of 1.27 (model 1) and 1.00 (model 2) which is within the benchmark value of 10 , this indicates the absence of multicollinearity in both models, and this means no independent variable should be dropped from the models. Also, from the table above, it can be observed that the OLS results had heteroscedasticity problems in model 1 since its probability value was significant at 5\% [7.66 (0.0056)] and no heteroscedasticity problems in model 2 since its probability value was insignificant at $1 \%$ or $5 \%$ [2.19 (0.1391)]. The presence of heteroscedasticity in model 1 clearly shows that our sampled firms are not homogeneous. This therefore means that a robust or panel regression approach will be needed to capture the impact of each firm heteroscedasticity on the results. In this study we adopted the panel regression method using both fixed and random effect models.

The F-statistic and Wald-statistic value [\{model 1: $38.11(0.00)\}$ model 2: $18.62(0.00)]$ and [\{model 1: $170.28(0.00)\}$ model 2: $47.22(0.00)]$ for fixed and random effect regression respectively shows that both models are valid for drawing inference since they are both statistically significant at $1 \%$. In the case of the coefficient of determination (R-squared), it was observed that [\{model 1:37\% \} model 2: 12\%] and [\{model 1:20\%\} model 2: 12\%] systematic variations in performance proxied by return on asset was explained jointly by the independent and control variables in both models respectively. This therefore implies that less of the variation in performance were explained when compared to the OLS pooled regression. In selecting from the two panel regression estimation results, the Hausman test was conducted, and the test is based on the null hypothesis that the random effect model is preferred to the fixed effect model. Specifically, for model 1, a look at the p-value of the Hausman test (0.0008), implies that we should reject the null hypothesis and accept the alternative hypothesis 
at above $5 \%$ or $1 \%$ level of significance. This implies that we should adopt the fixed effect panel regression results in drawing our conclusion and recommendations. This also implies that the fixed effect results tend to be more appealing statistically when compared to the random effect. However, for model 2, a look at the p-value of the Hausman test (0.8487), implies that we should accept the null hypothesis and reject the alternative hypothesis at above $5 \%$ or $1 \%$ level of significance. This implies that we should adopt the random effect panel regression results in drawing our conclusion and recommendations. This also implies that the random effect results tend to be more appealing statistically when compared to the fixed effect. Following the above, the discussion of the fixed and random effect results became imperative in testing our hypotheses for model 1 and 2 respectively. The below is a specific analysis for each of the independent variables using the fixed and random regression.

\section{DISCUSSION OF FINDINGS}

Since, the study is an extension of existing studies, only few findings in literature are not in agreement with the current positions of this study. Specifically, we find that structural capital efficiency (Fixed effect regression $=5.03(0.006)$ ) as an independent variable to performance appears to have a positive and significant influence on performance. This therefore means we should reject the null hypothesis $\left\{\mathrm{HO}_{1}\right.$ : Structural capital efficiency has no significant effect on performance of listed non-finance firms in Nigeria\}. This suggests that an increase in structural capital efficiency will significantly increase performance. This result agrees with prior empirical results which show that structural capital efficiency significantly increases performance (Ferenhof, Durst, Bialecki, \& Selig, 2015). However, we fail to agree with the studies of Phusavat, Comepa, Sitko-Lutek, \& Ooi, 2011; Ramezan \& Farahani, 2015; Low, Samkin, \& Li, (2015) who concluded that structural capital efficiency significantly decreases performance. Our results also shows that human capital efficiency (Fixed effect regression $=$ $0.21(0.129))$ as an independent variable to performance appears to have a positive and insignificant influence on performance. This therefore means we should accept the null hypothesis $\left\{\mathrm{HO}_{2}\right.$ : Human capital efficiency has no significant effect on performance of listed non-finance firms in Nigeria . This suggests that an increase in structural capital efficiency will insignificantly increase performance. This result agrees with prior empirical results which show that human capital efficiency insignificantly increases performance (Svanadze and Kowalewska, 2015). However, we fail to agree with the studies of Sawarjuwono \& Kadir, (2003) who concluded that human capital efficiency significantly decreases performance. We also provide evidence that capital employed efficiency (Fixed effect regression $=45.05$ $(0.000))$ as an independent variable to performance appears to have a positive and significant influence on performance. This therefore means we should reject the null hypothesis $\left\{\mathrm{HO}_{3}\right.$ : Capital employed efficiency has no significant effect on performance of listed non-finance firms in Nigeria\}. This suggests that an increase in capital employed efficiency will significantly increase performance. This result agrees with prior empirical results which show that capital employed efficiency significantly increases performance (Hitt et al., 2001). However, we fail to agree with the studies of Walker, (2001); Usoff et al., (2002); and Karp, (2003) who concluded that capital employed efficiency significantly decreases performance. As for the variable of value-added intellectual coefficient which represents model 2, our results shows that value-added intellectual coefficient (Random effect regression $=-0.01(0.000)$ ) as an independent variable to performance appears to have a positive and significant influence on 
performance. This therefore means we should reject the null hypothesis $\left\{\mathrm{HO}_{4}\right.$ : Value-added intellectual coefficient has no significant effect on performance of listed non-finance firms in Nigeria\}. This suggests that an increase in value-added intellectual coefficient will significantly increase performance. This result agrees with prior empirical results which show that value-added intellectual coefficient significantly increases performance (Goebel, 2015; Osinski, Selig, Matos \& Roman, 2017). However, we fail to agree with the studies of Cavicchi, 2017; Januškaite \& Užien, 2018; Gołacka, \& Jefmanska, \& Jefmanski, (2020) who concluded that value-added intellectual coefficient significantly decreases performance.

\section{CONCLUSION AND RECOMMENDATION}

Intellectual capital consists of intangible assets that can be converted into profits (and value) but are not reflected in firm financial statements. Researchers have highlighted different elements of intellectual capital depending on the research goals. Commonly, studies classify intellectual capital into three components: human capital (skills, experience, and competencies of employees); structural capital (processes, methods, and brands owned by a company); and relational capital (relation network). Intellectual capital positively affects firms' performance and encourages the process of value creation. Intellectual capital is the source of sustainable development. Further, In the knowledge economy, intellectual capital as an intangible resource can help a firm generate economic returns and build competitive advantage along with tangibles. The critical role of intellectual capital for the firm in balancing innovation and exploitative activities is further emphasized in the present fourth industrial revolution era, therefore, going forward, intellectual capital is the key assets for firm survival. In the light of this, the empirical result of this study leads to the conclusion that out of the four independent variables adopted in this study, only the variable of human capital efficiency insignificantly affect performance of listed non-finance firms in Nigeria. However, we conclude that structural capital efficiency, capital employed efficiency and value-added intellectual coefficient significantly improve firm performance. On the bases of these findings, we recommend that managers should place great emphasis on structural capital. They need to invest more in its human capital instruments through continuous learning and training. We recommend that managers should provide more towards proper training of employees and ensure that the right persons are selected for the job.

\section{REFERENCES}

Abeysekera, I. (2010). The influence of board size on intellectual capital disclosure by Kenyan listed firms. Journal of Intellectual Capital. 4(4), 319-342

Afandi, C. D. F., \& Riharjo, I. B. (2017). Pengaruh Intellectual Capital Terhadap Kinerja Perusahaan Yang Terdaftar Di Bursa Efek Indonesia. Jurnal Ilmu dan Riset Akuntansi (JIRA), 6(7).

Ahangar, R. G. (2011). The relationship between intellectual capital and financial performance: An empirical investigation in an Iranian company. African Journal of Business Management, 5(1), 88-95.

Cisneros, M., A., I. Perlines, F., I \& Garcia, M., R. (2020) Intellectual capital, organisational performance and competitive advantage," European Journal of International Management, 14, (6) 976-998. 
European Journal of Business and Innovation Research

Vol.10, No.1, pp. 1-17, 2022

Print ISSN: 2053-4019(Print),

Online ISSN: 2053-4027(Online)

Dumay, J., Guthrie, J., \& Rooney, J. (2020). Being critical about intellectual capital accounting in 2020: An overview. Critical Perspectives on Accounting, 70, 102185.

Kwan, S. (2003). Ownership structure and firm performance: Evidence from the banking industry. Unpublished paper, Federal Reserve Bank of San Francisco.

Lam, A. (2000). Tacit knowledge, organizational learning and societal institutions: An Integrated Framework. Organization Studies, 21(3), 487-513.

Latif, M., Malik, M. S., \& Aslam, S. (2012). Intellectual capital efficiency and corporate performance in developing countries: A comparison between Islamic and conventional banks of Pakistan. Interdisciplinary Journal of Contemporary Research in Business, 4(1), 405-420.

Majeed, S. (2011). The impact of competitive advantage on organizational performance. European Journal of Business and Management, 3(4), 191-196.

Martín-de-Castro, G., Delgado-Verde, M., López-Sáez, P., \& Navas-López, J. E. (2011). Towards 'an intellectual capital-based view of the firm': origins and nature. Journal of business ethics, 98(4), 649-662.

Martins, M. M., \& Lopes, I. T. (2016). Intellectual capital and profitability: A firm value approach in the European companies. (3), 234-242.

Matos, F., Vairinhos, V., Selig, P. M., \& Edvinsson, L. (2019). Intellectual capital management as a driver of sustainability. Perspectives for Organizations and Society, Springer International Publishing, Cham and Berlin.

Nielsen, C., \& Madsen, M. T. (2009). Discourses of transparency in the intellectual capital reporting debate: Moving from generic reporting models to management defined information. Critical Perspectives on Accounting, 20(7), 847-854.

Nik Maheran, N.M., Filzah, M.I. \& Nik Rozhan, N.I. (2009), Intellectual capital efficiency level of Malaysian financial sector: Panel data analysis (2002-2006),

Nimtrakoon, S. (2015) The relationship between intellectual capital, firms' market value and financial performance-Empirical evidence from the ASEAN. Journal of Intellectual Capital. (16) 587-618.

Nimtrakoon, S. (2015). The relationship between intellectual capital, firms' market value and financial performance: Empirical evidence from the ASEAN. Journal of Intellectual Capital. 48(3), 450-463.

Nonaka, I., \& Takeuchi, H. (1997). A new organizational structure. Knowledge in Organisations, 99-133.

Novak, S., \& Wernerfelt, B. (2012). On the grouping of tasks into firms: Make-or-buy with interdependent parts. Journal of Economics \& Management Strategy, 21(1), 53-77.

Ogbo, A., Ezeobi, J., \& Ituma, A. (2013). Impact of intellectual capital on organizational performance: Evidence from Nigeria banking sector. Journal of Research in National Development, 11(2), 249-254.

Pratama, Y. H., \& Achmad, T. (2015). Pengaruh Intellectual Capital Terhadap Kinerja Perusahaan Dengan Competitive Advantage Sebagai Variabel Intervening (Studi Pada Perusahaan Perbankan yang Terdaftar di BEI 2009-2013) (Doctoral dissertation, Fakultas Ekonomika dan Bisnis).

Pulic, A. \& Bornemann, M. (1997), The Physical and Intellectual Capital of Austrian Banks,

Pulic, A. (2000) VAIC - An accounting tool for intellectual capital management. International Journal of Technology Management (20) 702-714. 
European Journal of Business and Innovation Research

Vol.10, No.1, pp. 1-17, 2022

Print ISSN: 2053-4019(Print),

Online ISSN: 2053-4027(Online)

Pulic, A. (2000), MVA \& VAICTM analysis of randomly selected companies from FTSE 250, Austrian Intellectual Capital Research Center, Graz and London.

Pulic, A. (2004) Intellectual capital-Does it create or destroy value? Measuring Business Excellence (8) 62-68.

Roose, G.; Pike, S.; Fernstro, L. (2005) Managing intellectual capital in practice; Elsevier: New York, NY, USA.

Shakina, E., Barajas, A., \& Molodchik, M. (2017). Bridging the gap in competitiveness of Russian companies with intangible bricks. Measuring Business Excellence. 48(3), 450463.

Soewarno, N., \& Tjahjadi, B. (2020). Measures that matter: an empirical investigation of intellectual capital and financial performance of banking firms in Indonesia. Journal of Intellectual Capital. 48(3), 450-463.

Solikhah, B. (2010). An extended theory of reason action model of CPA Career: An Indonesian

Sugeng, I. (2002). Mengukur dan Mengelola Intellectual Capital. Paradigma Baru Manajemen Sumber Daya Manusia. Editor A. Usmara.

Svanadze, S., \& Kowalewska, M. (2015). The measurement of intellectual capital by VAIC method-example of WIG20. Online Journal of Applied Knowledge Management, 3(2), $36-44$.

Sveiby, K. E. (1997). The new organizational wealth: Managing \& measuring knowledgebased assets. Berrett-Koehler Publishers.

Sveiby, K.E. (1997), The new organizational wealth: Managing and measuring knowledgebased assets, Berrett-Koehler Publishers, San Francisco.

Tan, H. P., Plowman, D., \& Hancock, P. (2007). Intellectual capital and financial returns of companies. Journal of Intellectual capital. 7(1), 23-36.

Tarawneh, M. (2006). A comparison of financial performance in the banking sector: Some evidence from Omani commercial banks. International Research Journal of Finance and Economics, 3(3), 101-112.

Tayles, M., Pike, R. H., \& Sofian, S. (2007). Intellectual capital, management accounting practices

Vargo, S. L., \& Lusch, R. F. (2004). Evolving to a new dominant logic for marketing. Journal of Marketing, 68(1), 1-17.

Venkatraman, N. \& Ramanujam, V. (1986), -Measurement of Business Performance in Strategy Research: A Comparison of Approachesll, Academy of Management Review, (11), 801-814.

Zott, C. (2003). Dynamic capabilities and the emergence of intra-industry differential firm performance: Insights from a simulation study. Strategic Management Journal, 24(2), 97-125. 